\title{
Biodegradation of Bonnylight crude oil by locally isolated fungi from oil contaminated soils in Akure, Ondo state
}

\author{
Fatuyi Olanipekun Ekundayo *, Oluwatoyin Folake Olukunle and Esther Aanuoluwa Ekundayo. \\ Department of Microbiology, Federal University of Technology, P. M. B. 704, Akure, Ondo State, Nigeria \\ E-mail: foekundayo2002@yahoo.com \\ Received 15 January 2011; received in revised form 20 September 2011; accepted 26 December 2011
}

\begin{abstract}
Aim: This present investigation was conducted to determine the capability of fungi isolated from soil samples collected from two automobile workshopsto bioremediate Bonnylight crude oil.

Methodology and Results: The fungi present on the soil samples collected from two automobile workshops in Akure, Nigeria were investigated using standard microbiological techniques. These fungal isolates were screened for the ability to degrade Bonnylight crude oil. The bioremediation of Bonnylight crude oil was observed spectrophotometrically using the broth culture (non- harvested cells) and harvested cells of the fungi isolated from the contaminated sites for a period of 20 days on minimal salt broth. Mycotypha microspora, Penicllium italicum, Botryris cinerea, Gliocladium deliquescence, Verticillium albo-atrum and Aspergillus niger were isolated from the contaminated site while Neurospora crassa, A. parasiticus, A. niger and Gonatobotryum apiculatum were isolated from uncontaminated sites. All the fungal isolates were capable of active degradation in varying degrees.

Conclusion: The study shows that all the isolated fungi were capable of degrading the crude oil in varying degrees. The active crude oil utilizing fungi in this study were Aspergillus niger (both harvested and non harvested cells) and Gliocladium deliquescence (non harvested cells) and Penicillium italicum (harvested cells). Aspergillus niger has best degrading ability than other fungi in non harvested and harvested cell condition. However, non harvested cells recorded the higher degradative ability than harvested cells. Therefore, non harvested cells can be employed in bioremediation of Bonnylight crude oil.
\end{abstract}

Significance and Impact of Study: The fungi isolated from automobile mechanic workshops contaminated soil can be exploited in the bioremediation of Bonny Light crude oil.

Keywords: fungi, degradation, harvested cells, bioremediation

\section{INTRODUCTION}

Petroleum is at present Nigeria's and indeed the world's most important derived energy source (Moffat and Linden, 2005). Petroleum in its natural state is referred to as crude oil (Ukoli, 2003). Crude oil is mainly either black or green but it can also be light yellow (Onifade et al., 2007). It varies considerably in density and is described as heavy, average or light (Ojo and Adebusuyi, 1996). Crude oil is one of the most significant pollutants in the environment as it is capable of causing serious damages to humans and the ecosystem (Okpokwasili, 1996).

Pollution is an undesirable change in the physical, chemical and biological characteristics of all the components of an environment (Aboriba, 2001). The greatest single environmental problem connected with crude oil exploration in Nigeria is oil spillage at both onshore and offshore. The rate of oil spillage reported in the country has been rising with a corresponding increase in petroleum production (Onifade et al., 2007).

The primary aims of any remediation are reduction of actual or potential environmental threat and reduction of potential risks so that unacceptable risks are reduced to acceptable levels (Atlas, 1995). Consequently, the need for remediation will depend on the degree of actual or potential environmental threat or the level of risk (Ukoli, 2003). Remediation of a contaminated site is achieved by one or more of the following objectives: Removal or destruction of the contaminants, modification of the contaminants to a less toxic form and isolation of the contaminant from the target by interrupting the pathway of exposure (Onifade et al., 2007).

It is known that greater degradation of oil pollutants is carried out in situ by a consortium of microorganisms (Okpokwasili, 1996; 2003) and more than 200 species of bacteria, fungi and even algae are capable of degrading hydrocarbons because of their ubiquitous nature. Various genera that have been reported to contain hydrocarbon degrading species include Pseudomonas, Vibrio, Corynebacterium, Arthrobacter, Brevibacterium, Staphylococcus, Bacillus, Thiobacillus, Penicillium, Candida, Fusarium, Aspergillus, Talaromyces and Articulosporium (Snape et al., 2001). These organisms have been isolated in large numbers from many oil 
polluted waters and soils but are found in less numbers in uncontaminated environments (Okoh, 2003). In this present investigation, bioremediation was carried out on Bonnylight crude oil using fungi isolated from soil samples collected from two automobile workshops in Akure by measuring the optical density (OD).

\section{MATERIALS AND METHODS}

\section{Collection of samples}

Soil samples were collected from two mechanic workshops located at FUTA road and Orita Obele junction, Akure. Uncontaminated soil sample served as control. The samples were aseptically collected with the aid of soil auger, stored in sterile aluminium foils and transported to the laboratory within $48 \mathrm{~h}$ of collection. Bonnylight crude oil was collected from Port Harcourt in Nigeria.

\section{Isolation, identification and characterization of fungi}

Three-fold serial dilution was performed on the above soil samples. An aliquot $(0.2 \mathrm{~mL})$ of each diluent were plated on sterile potato dextrose agar (PDA) using the pour plate method. Incubation was done at $28 \pm 2{ }^{\circ} \mathrm{C}$ for three days. Developing fungal cultures were aseptically subcultured a number of times into fresh PDA plates and incubated $28 \pm$ $2{ }^{\circ} \mathrm{C}$ for three days until pure cultures of fungi were obtained. Pure cultures were afterwards transferred onto McCartney bottles of PDA slant incubated at $28 \pm 2{ }^{\circ} \mathrm{C}$ for three days and stored at $4{ }^{\circ} \mathrm{C}$ in the refrigerator. To identify the fungi, morphological studies such as examination of the size, shape, colour, spore formation and the number of days taken for the fungus to reach maximum diameter $(9 \mathrm{~cm})$ of the Petri dish and the texture of fungal growth were observed. The fungi, the sporebearing mycelia were then carefully sectioned, teased out and stained on a slide and then observed with a light microscope. The fungi were then identified and characterized according to the method of Carpenter (1977).

\section{Preparation of fungal culture and harvested cells}

A sterile needle was employed to pick fungal mycelia and inoculated on sterile potato dextrose broth and incubated at $28 \pm 2{ }^{\circ} \mathrm{C}$ for three days. For the harvested cells, the broth cultures were centrifuged at $3000 \mathrm{rpm}$ (Centrifuge MSE Minor 35) for five min and resuspended in $2 \mathrm{~mL}$ sterile distilled water. The content was centrifuged again at $3000 \mathrm{rpm}$ for five min to wash the cells. Harvested cells were obtained after decanting the supernatant.

\section{Test for degradation of Bonnylight crude oil}

The enrichment procedure as described by Nwachukwu (2000) was used in the estimation of hydrocarbon utilizers. The medium contained $\mathrm{Na}_{2} \mathrm{HPO}_{4}(2.0 \mathrm{~g}), \mathrm{K}_{2} \mathrm{SO}_{4}(0.17 \mathrm{~g})$, $\mathrm{NH}_{4} \mathrm{NO}_{3}(4.0 \mathrm{~g}), \mathrm{KH}_{2} \mathrm{PO}_{4}(0.53 \mathrm{~g}), \mathrm{MgSO}_{4} \cdot 7 \mathrm{H}_{2} \mathrm{O}$ and 1000 $\mathrm{ml}$ of distilled water. Sterilization was done at $121{ }^{\circ} \mathrm{C}$ for $15 \mathrm{~min}$. Each isolate $(1 \mathrm{~mL}$ of harvested and non harvested cells) was inoculated into $10 \mathrm{~mL}$ of the basal medium with $2 \mathrm{~mL}$ crude oil (Bonnylight) in test tubes. Each of the test tubes was plugged with sterile cotton wool wrapped with Aluminium foil so as to ensure maximum aeration and prevent cross-contamination. All the test tubes were then incubated at room temperature $28^{\circ} \mathrm{C}$ for 20 days during which degradation of Bonnylight crude oil was monitored by reading the OD at $540 \mathrm{~nm}$ at five days interval. The experiment was done in replicates. The uncontaminated sites served as control.

\section{RESULTS AND DISCUSSION}

Different species of fungi was associated with the soil samples collected from the two automobile workshops. $M$. microspora, P. italicum, B. cinerea, G. deliquescence, $V$. albo-atrum and $A$. niger were isolated from the contaminated site while $N$. crassa, $A$. parasiticus, $A$. niger and $G$. apiculatum were isolated from the uncontaminated sites. Effects of incubation period on the degrading ability of the isolated fungi from contaminated sites are presented in Figures 1 to 8 . Progressive increase in absorbance was recorded for both non harvested and harvested cells of fungi inoculated onto the crude oil except for harvested cells of $M$. microspora and $B$. cinerea. Considering the non harvested cells on the $20^{\text {th }}$ day, the highest degradative capacity was observed in $A$. niger followed by $G$. deliquescence, M. microspora, $P$. italicum, $B$. cinerea and $V$. albo-atrum with $\mathrm{OD}$ of $0.82 \pm 0.21$, $0.77 \pm 0.01, \quad 0.63 \pm 0.04, \quad 0.55 \pm 0.18, \quad 0.50 \pm 0.04$ and $0.43 \pm 0.06$ respectively. However, for harvested cells, $A$. niger also had the highest degradative ability followed by $P$. italicum, M. microspora, G. deliquescence, B. cinerea and $V$. albo-atrum with $\mathrm{OD}$ of $0.33 \pm 0.02,0.30 \pm 0.03$, $0.28 \pm 0.00, \quad 0.25 \pm 0.02, \quad 0.22 \pm 0.03$ and $0.21 \pm 0.11$ respectively on $20^{\text {th }}$ day. For the uncontaminated sites, it was also observed that $A$. niger appeared to be the best degrader while $N$. crassa was the least as shown in Table 1. Generally however, non harvested cells of $A$. niger in contaminated sites had the degradative ability.

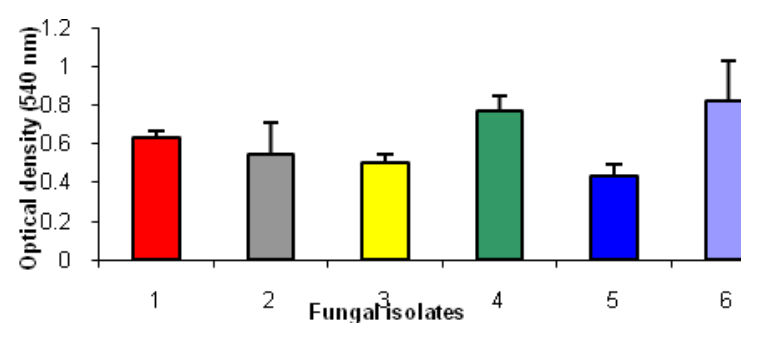

Figure 1:Degradative ability of harvested cells of fungi isolated from soil samples on $5^{\text {th }}$ day. 1: M. microspora, 2: $P$. italicum, 3: B. cinerea, 4: G. deliquenscens, 5: V. alboatrum, 6: $A$. niger. 


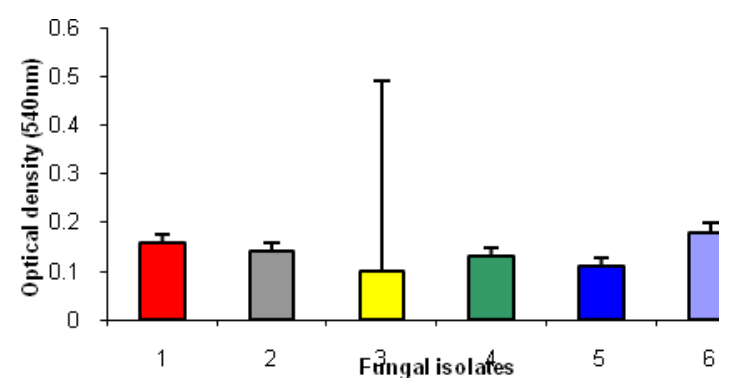

Figure 2: Degradative ability of harvested cells of fungi isolated from soil samples on $10^{\text {th }}$ day. $1:$ M. microspora, 2 : P. italicum, 3: B. cinerea, 4: G. deliquenscens, 5: V. alboatrum, 6: $A$. niger.

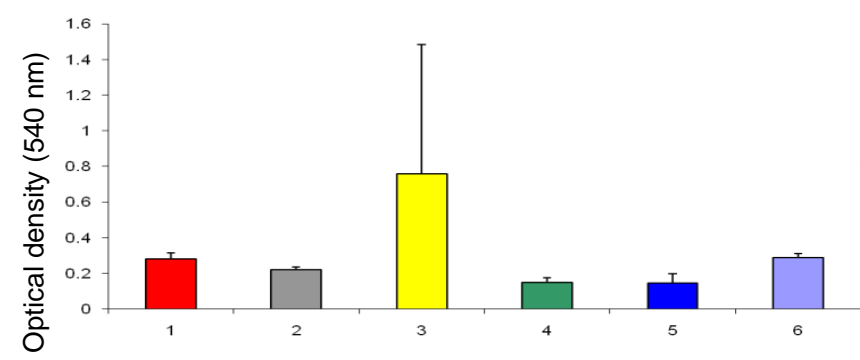

Figure 3: Degradative Fubifitl isolates isolated from soil samples on $15^{\text {th }}$ day. 1: M. microspora, 2 : $P$. italicum, 3: B. cinerea, 4: G. deliquenscens, 5: V. alboatrum, 6: $A$. niger.

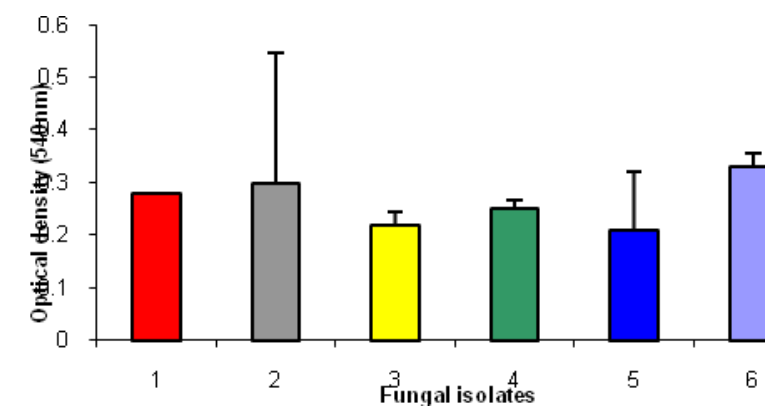

Figure 4: Degradative ability of harvested cells of fungi isolated from soil samples on $20^{\text {th }}$ day. $1:$ M. microspora, 2: $P$. italicum, 3: B. cinerea, 4: G. deliquenscens, 5: V. alboatrum, 6: $A$. niger.

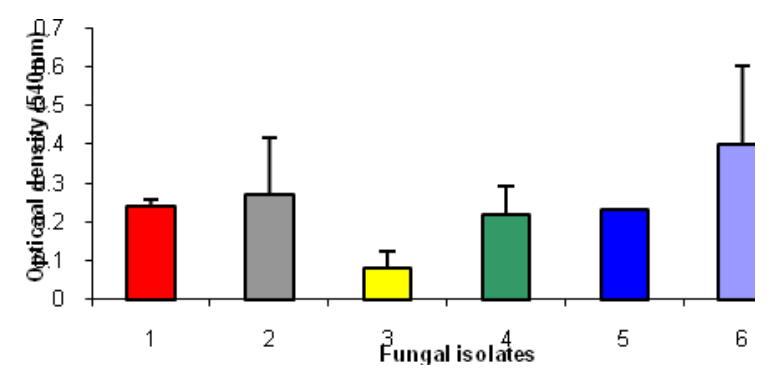

Figure 5: Degradative ability of non-harvested cells of fungi isolated from soil samples on $5^{\text {th }}$ day. 1: $M$. microspora, 2: $P$. italicum, 3: $B$. cinerea, 4: $G$. deliquenscens, 5: $V$. albo-atrum, 6: A. niger.

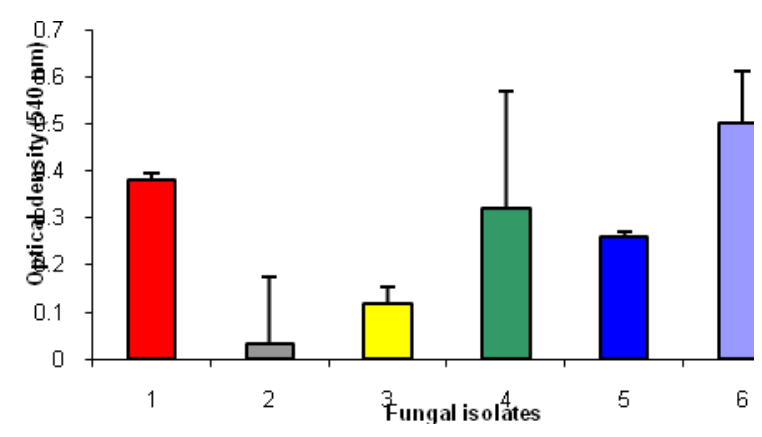

Eigure 6: Degradative ability of non-harvested cells of ferngi isolated from soil samples on 10th day. 1: $M$. microspora, 2: P. italicum, 3: B. cinerea, 4: G. geliquenscens, 5: V. albo-atrum, 6: A. niger.

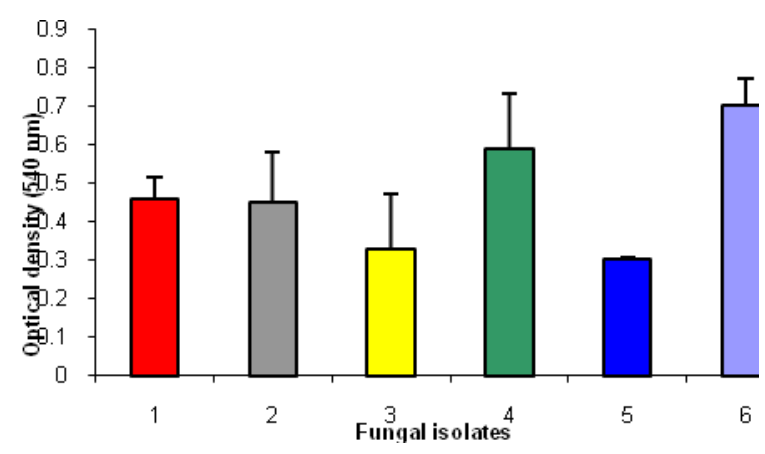

Figure 7: Degradative ability of nonharvested cells of fungi isolated from soil samples on $15^{\text {th }}$ day. 1: $M$. microspora, 2: $P$. italicum, 3: $B$. cinerea, 4: $G$. deliquenscens, 5: $V$. albo-atrum, 6: A. niger.

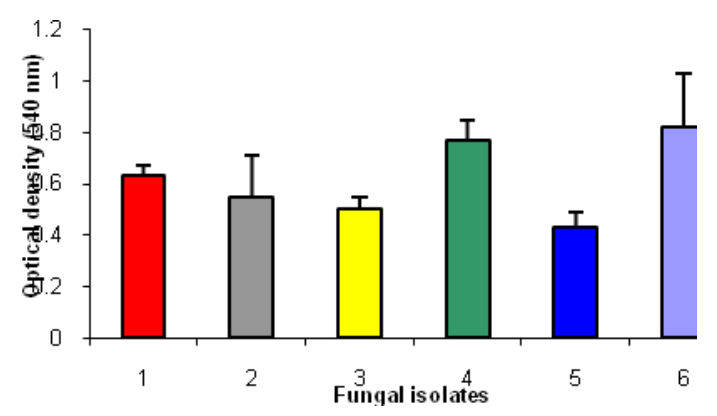

Figure 8: Degradative ability of non-harvested cells of fungi isolated from soil samples on $20^{\text {th }}$ day. 1: $M$. microspora, 2: P. italicum, 3: B. cinerea, 4: G. deliquenscens, 5: $V$. albo-atrum, 6: A. niger. 
Table 1: Degradative ability of fungi isolated from uncontaminated soil samples.

\begin{tabular}{llccc}
\hline $\begin{array}{l}\text { Period } \text { of incubation } \\
\text { (Day) }\end{array}$ & \multicolumn{4}{c}{ Optical density $(\mathrm{nm})$ of fungal isolates from un contaminated sites } \\
\cline { 2 - 5 } & A. niger & A. parasiticus & G. apiculatum & N. crassa \\
\hline 5 & $0.194 \pm 0.010$ & $0.380 \pm 0.010$ & $0.580 \pm 0.020$ & $0.720 \pm 0.010$ \\
10 & $0.120 \pm 0.020$ & $0.230 \pm 0.002$ & $0.320 \pm 0.002$ & $0.440 \pm 0.030$ \\
15 & $0.120 \pm 0.020$ & $0.210 \pm 0.002$ & $0.360 \pm 0.002$ & $0.460 \pm 0.002$ \\
20 & $0.120 \pm 0.000$ & $0.190 \pm 0.020$ & $0.280 \pm 0.020$ & $0.380 \pm 0.000$ \\
\hline
\end{tabular}

Table 2: Comparative degradative ability of harvested and non harvested cells of fungal isolates on different days.

\begin{tabular}{|c|c|c|c|c|c|c|c|c|c|c|c|c|c|}
\hline \multirow{2}{*}{ Days } & \multicolumn{13}{|c|}{ Optical density (nm) of fungal isolates } \\
\hline & HMM & $\mathrm{NHMI}$ & & $\mathrm{HPI}$ & NHPI & $\mathrm{HBC}$ & NHBC & HGD & NHGD & HVA & NHVA & HAN & NHAN \\
\hline & $0.10 \pm$ & 0.24 & \pm & $0.11 \pm$ & $0.27 \pm$ & $0.06 \pm$ & $0.08 \pm$ & $0.08 \pm$ & $0.22 \pm$ & $0.07 \pm$ & $0.23 \pm$ & $0.13 \pm$ & $0.40 \pm$ \\
\hline 5 & 0.02 & 0.02 & & 0.04 & 0.15 & 0.05 & 0.05 & 0.03 & 0.08 & 0.02 & 0.00 & 0.02 & 0.20 \\
\hline 10 & $0.16 \pm$ & 0.38 & \pm & $0.14 \pm$ & $0.34 \pm$ & $0.10 \pm$ & $0.12 \pm$ & $0.13 \pm$ & $0.32 \pm$ & $0.11 \pm$ & $0.26 \pm$ & $0.18 \pm$ & $0.50 \pm$ \\
\hline & 0.02 & 0.02 & & 0.02 & 0.14 & 0.40 & 0.04 & 0.02 & 0.25 & 0.02 & 0.01 & 0.03 & 0.11 \\
\hline 15 & $\begin{array}{l}0.28 \pm \\
0.04\end{array}$ & $\begin{array}{l}0.46 \\
0.06\end{array}$ & \pm & $\begin{array}{l}0.22 \pm \\
0.02\end{array}$ & $\begin{array}{l}0.45 \pm \\
0.13\end{array}$ & $\begin{array}{l}0.76 \pm \\
0.73\end{array}$ & $\begin{array}{l}0.33 \pm \\
0.14\end{array}$ & $0.15 \pm$ & $\begin{array}{l}0.59 \pm \\
0.14\end{array}$ & $\begin{array}{l}0.14 \pm \\
0.05\end{array}$ & $0.30 \pm$ & $0.29 \pm$ & $0.70 \pm$ \\
\hline 20 & $\begin{array}{l}0.28 \pm \\
0.00\end{array}$ & $\begin{array}{l}0.63 \\
0.04\end{array}$ & \pm & $\begin{array}{l}0.30 \pm \\
0.03\end{array}$ & $\begin{array}{l}0.55 \pm \\
0.18\end{array}$ & $\begin{array}{l}0.22 \pm \\
0.03\end{array}$ & $\begin{array}{l}0.50 \pm \\
0.05\end{array}$ & $\begin{array}{l}0.25 \pm \\
0.02\end{array}$ & $\begin{array}{l}0.76 \pm \\
0.08\end{array}$ & $\begin{array}{l}0.21 \pm \\
0.12\end{array}$ & $\begin{array}{l}0.43 \pm \\
0.06\end{array}$ & $\begin{array}{l}0.33 \pm \\
0.03\end{array}$ & $\begin{array}{l}0.82 \pm \\
0.21\end{array}$ \\
\hline
\end{tabular}

Values are means of three replicates

HMM: Harvested cells of M. microspora, NHMM: Non harvested cells of $M$. microspora, HPI: Harvested cells of $P$. italicum, NHPI: Non harvested cells of $P$. italicum, HBC: Harvested cells of $B$. cinerea, NHBC: Non harvested cells of $B$. cinerea, HGD: Harvested cells of $G$. deliquenscens, NHGD: Non harvested cells of G. deliquenscens, HVA: Harvested cells of $V$. albo-atrum, NHVA: Non harvested cells of $V$. albo-atrum, HAN: Harvested cells of $A$. niger, NHAN: Non harvested cells of $A$. niger.

The fact that these organisms were isolated from these samples was a testament that they were able to exist in the oil spilled environment while those that could not survive in this environment were eliminated by the unfavourable condition caused by the oil. The results of the degradative ability of the isolated fungi showed that all the organisms maximally utilized Bonnylight crude oil. This might be due to the fact that the fungi isolated were able to use the hydrocarbons as substrates for growth by probably releasing extra cellular enzymes and acids which are capable of breaking down the recalcitrant hydrocarbon molecules, by dismantling the long chains of hydrogen and carbon, thereby, converting petroleum into simpler forms or products that can be absorbed for the growth and nutrition of the fungi (Adekunke and Adebambo, 2007). Okerentugba and Ezeronye (2003) demonstrated that Penicillium spp., Aspergillus spp. and Rhizopus spp. were capable of degrading hydrocarbons especially when single cultures were used. Snape et al. (2001) also reported that Penicillium, Candida, Fusarium, Aspergillus, Talaromyces and Articulosporium are among fung capable of bioremediation. Atlas (1995) reported that crude oil contains hydrocarbon that does not resist attack by microorganisms. Batelle (2000) showed that fungi were better degraders than traditional bioremediation techniques including bacteria. The degradative ability increased with period of incubation period in all the fungal isolates. This was also observed by Omoya et al. (2009). Results of this present study show that the utilization of Bonnylight crude oil varied widely among the fung isolated. Generally, $V$. albo-atrum had the least degradative capability for both non harvested and harvested cells while the highest degrader was $A$. niger.
Similar result was observed by Adekunle and Adebambo (2007) in which $A$. niger had the highest OD on the $40^{\text {th }}$ day of incubation. This might be a as a result of the difference in growth rates and molecular sizes of each fungus or exhaustion of nutrients and release of toxic materials into the medium.

\section{CONCLUSIONS}

The study shows that all the isolated fungi were capable of degrading the crude oil in varying degrees. The active crude oil utilizing fungi in this study were $A$. niger (both harvested and non harvested cells) and $G$. deliquescence (non-harvested cells) and $P$. italicum (harvested cells). $A$. niger has best degrading ability than other fungi in non harvested and harvested cell condition. However, non harvested cells recorded the higher degradative ability than harvested cells. Therefore, non harvested cells can be employed in bioremediation of Bonnylight crude oil. The fungi isolated from contaminated soil samples can be exploited in the bioremediation of crude oil.

\section{REFERENCES}

Aboriba, R. I. (2001). Oil politics and Niger Delta development commission. The Tussle for Control and Domination. African Journal of Environmental Studies 2, 168-175.

Adekunle, A. A. and Adebambo, O. A. (2007). Petroleum hydrocarbon utilization by fungi isolated from Detarium Senegalense (J. F Gmelin) seeds. The Journal of American Science 3, 69-76. 
Atlas, R. M. (1995). Bioremediation of petroleum pollutants. International Bioremediation and Biodegradation 35, 317-327.

Batelle, C. D. (2000). Mushrooms: Higher macrofungi to clean up the environment. Batelle Environmental Issues, Fall 2000

Carpenter, P. L. (1977). Microbiology. $4^{\text {th }}$ Edn. W. B. Saunders Company, Philadelphia, pp 401-402.

Moffat, A. O. and Linden, P. (2005). Perception and reality. Journal of Environmental Science and Technology 1, 283-297.

Nwachukwu, S. C. U. (2000). Enhanced rehabilitation of tropical aquatic environment polluted with crude petroleum using Candida utilis. Journal of Environmental Biology 21, 241-250.

Ojo, M. O. and Adebusuyi, B. S. (1996). The state of the Nigerian petroleum industry: Performance, problems and outstanding issues. CBN Economic and Financial Review Vol. 34, September

Okerentugba, P. O. and Ezeronye, O. U. (2003). Petroleum degrading potentials of single and mixed microbial cultures isolated from rivers and refinery effluent in Nigeria. African Journal of Biotechnology 2, 288-292.

Okoh, A. I. (2003). Biodegradation of Bonny light crude oil in soil microcosm by some bacterial strains isolated from crude oil flow stations saver pits in Nigeria. African Journal of Biotechnology 2 (5), 104108

Okpokwasili, G. C. (1996). Microbial degradation of petroleum hydrocarbon by brackish water isolates in Nigerian wetlands. In: The Nigerian Man and The Biosphere. Akpata, T. V. I. and Aven, O. (Eds.) (M.AB-5) National Committee, pp. 13-146. Okpokwasili, G. C. (2003). Biodeterioration potentials of microorganism isolated from car engine lubricating oil. Tribology International 21, 215-220.

Omoya, F. O., Boboye, B. E. and Akinyosoye, F. A. (2009). Mosquito degradative potential of mosquito and cockroach borne bacteria. Journal of Medical Sciences 9, 202-207.

Onifade, A. K., Abubakar, F. A. and Ekundayo, F. O. (2007). Bioremediation of crude oil polluted soil in the Niger Delta area of Nigeria using enhanced natural attenuation. Research Journal of Applied Sciences 2, 498-504.

Snape, I., Riddle, M. J., Stark, J. S., Cole, C. M. and Gore, D. B. (2001). Management and remediation of contaminated sites at Casey station. Antarctica Polar Record 37, 199-214.

Ukoli, M. K. (2003). Environmental factors in the management of the oil and gas industries in Nigeria. Nigerian National Petroleum Corporation (NNPC) p2. 